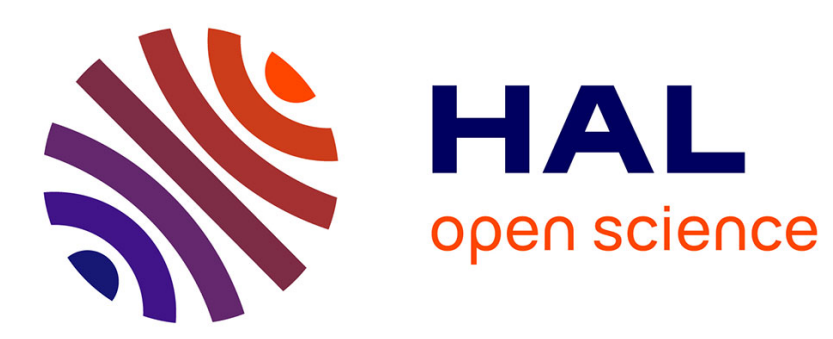

\title{
Eco-EAR: A method for the economic analysis of urban water systems providing services
}

\author{
Amir Nafi, Y. Bentarzi, Damien Granger, Frédéric Cherqui
}

\section{To cite this version:}

Amir Nafi, Y. Bentarzi, Damien Granger, Frédéric Cherqui. Eco-EAR: A method for the economic analysis of urban water systems providing services. Urban Water Journal, 2014, 11 (6), pp.1-12. 10.1080/1573062X.2013.868497 . hal-00996985

\section{HAL Id: hal-00996985 \\ https://hal.science/hal-00996985}

Submitted on 16 May 2020

HAL is a multi-disciplinary open access archive for the deposit and dissemination of scientific research documents, whether they are published or not. The documents may come from teaching and research institutions in France or abroad, or from public or private research centers.
L'archive ouverte pluridisciplinaire HAL, est destinée au dépôt et à la diffusion de documents scientifiques de niveau recherche, publiés ou non, émanant des établissements d'enseignement et de recherche français ou étrangers, des laboratoires publics ou privés. 


\title{
Eco-EAR: a method for the economic analysis of urban water systems providing services
}

\author{
Amir NAFI ${ }^{1}$, Younes BENTARZI ${ }^{1}$, Damien GRANGER ${ }^{2,3}$ and Frederic \\ CHERQUI $^{4,5}$.
}

\footnotetext{
${ }^{1}$ Unité Mixte de Recherche Gestion territoriale de l'Eau et de l'Environnement (GESTE) IRSTEAENGEES, 1 quai koch 67070 Strasbourg Cedex, France.

1 amir.nafi@engees.unistra.fr.

1younes.bentarzi@engees.unistra.fr.

${ }^{2}$ Lyonnaise des Eaux, Agence Haut-Rhin, 17 rue Guy de Place - BP 68802 Thann Cedex.

${ }^{3}$ LyRE, centre de recherche de Lyonnaise des Eaux Bordeaux, domaine du Haut-Carré, Bâtiment C4, 2nd étage, aile gauche - 33400 Talence.

2,3 damien.granger@1yonnaise-des-eaux.fr.

${ }^{4}$ Université Lyon 1, LGCIE, 69622, Villeurbanne, France.

${ }^{5}$ Université de Lyon, 69361, Lyon, France.

4,5 frederic.cherqui@insa-lyon.fr.
}

\section{Corresponding author: Doctor Amir NAFI}

Email address: amir.nafi@engees.unistra.fr

Postal address: 1 quai Koch 67070 Strasbourg Cedex., France

Telephone number: +33 388248293

Fax number: +33 388248284 


\title{
Eco-EAR: a method for the economic analysis of urban water systems providing services
}

\author{
Amir NAFI ${ }^{1}$, Younes BENTARZI ${ }^{1}$, Damien GRANGER ${ }^{2,3}$ and Frederic \\ $\mathrm{CHERQUI}^{4,5}$. \\ ${ }^{1}$ Unité Mixte de Recherche Gestion territoriale de l'Eau et de l'Environnement (GESTE) IRSTEA-ENGEES, 1 quai Koch 67070 Strasbourg \\ Cedex, France. \\ ${ }^{2}$ Lyonnaise des Eaux, Agence Haut-Rhin, 17 rue Guy de Place - BP 68802 Thann Cedex, France. \\ ${ }^{3}$ LyRE, centre de recherche de Lyonnaise des Eaux Bordeaux, domaine du Haut-Carré, Bâtiment C4, 2nd étage, aile gauche - 33400 Talence, \\ Frances. \\ ${ }^{4}$ Université Lyon 1, LGCIE, 69622, Villeurbanne, France. \\ ${ }^{5}$ Université de Lyon, 69361, Lyon, France.
}

\begin{abstract}
In the context of new challenges and emerging needs for transparency regarding users, urban water management is obliged to forge links between different technical fields. This implies managing interfaces between multiple stakeholders on the one hand, and ensuring the adaptability and sustainability of technical infrastructures on the other hand. In a period dominated by public spending cuts, the optimisation and efficiency of the system's infrastructures and the organisation of the stakeholders involved has become important for guaranteeing the continuity of the services provided. From the economic viewpoint, this challenge is related to tracking and reducing costs. Moreover, it also concerns the need to communicate arguments related to service costs to both users and stakeholders. Consequently, the "Eco-EAR" method was developed by adapting Functional Analysis (FA), Activity Based Costing (ABC) and Whole Life Costing (WLC) approaches in view to describing how the direct costs of the sewerage service provided by wastewater utilities are structured. The cost structure is analysed according to the activities and physical flows comprising the primary and secondary functions of an urban water management system. Three goals are targeted: i) to explain the costs of the system to the local authority (owners) and users; ii) to identify the activities that have the greatest impact on costs in order to plan cost reduction actions; and iii) to assess the apportionment of costs per activity and per physical flow, in order to better understand the system by combining both its economic and technical dimensions. The performance indicators proposed by the "Eco-EAR" method could also be used for benchmarking. The method is implemented in a real case study: the sub-system territory around the city of Mulhouse (northeast France) under the responsibility of a water management authority.
\end{abstract}

Keywords: asset, direct cost, function, flow, integrated management, indicator, sewers, urban water, wastewater system. 


\section{Introduction}

Water, wastewater and stormwater management systems have evolved independently since first being set up, in order to adapt to changing cities and lifestyles. Urban water management must reflect the city and its evolutions. The driving forces behind these evolutions are numerous and have diverse origins. Social and societal evolutions occur with higher expectations regarding levels of service and populations while political changes result in increasingly complex regulations and institutions, making the governance of urban water more complex. In addition, environmental evolutions have to be taken into account, by considering global changes and their consequences (climate change, resources depletion, decrease of water consumption). The evolution of technologies means that there are new possibilities for monitoring, innovative recovery processes and, finally, economic changes occur with cuts in public budgets, energy optimisation and new added value processes. Importantly, urbanisation has had significant impacts on the urban water cycle (Chocat et al. 2007). The pressure affecting cities and, in our context, urban water system has led to the need to consider more functions, thus making it necessary to expand the boundaries of the system. This will enable the promotion of functions such as ecosystem protection, water stress mitigation, adaptability, and the re-utilisation of storm and waste waters. Numerous studies on these functions have been published (Ashley et al. 2002; Ashley et al. 2007, Chocat et al. 2007, Fletcher et al. 2009; Novotny and Brown 2007; Wong et al. 2008).

Two major international conferences held in 1992 encouraged the emergence of the new paradigm for water management: i) the Conference on Water and the Environment in Dublin (Ireland) and ii) the Conference on Sustainable Development in Rio de Janeiro (Brazil). They contributed to the birth of the concept of "integrated water management, IWRM". EPRI (2010) compared the classical situation with the new paradigm and highlighted the mutation of the urban water management system (UWMS). A UWMS is a multifunctional system as it fulfils several standard technical functions to which new ones must be added: recreational activities, the embellishment of public areas, the improvement of living environment, environmental conservation and the prevention of pollution, the encouragement of reutilisation and recycling, etc. UWMS into a combination of decentralised sub-systems, governed collaboratively. The urban areas of a watershed are areas in which water should be managed in an integrated and sustainable way. 
The concept of IWRM emerged due to the inability of sectorial and centralised approaches to achieve the sustainable and globally efficient management of water resources for a range of uses and several stakeholders (institutions, authorities, clients, population, agriculture, industry, tourism, others). The deployment of IWRM was encouraged by the fact that environmental legislation in developed countries incorporates sustainability requirements and internalises the principles of integrated water management. According to Varis (2005) the concept of IWRM aims at using water to ensure the well-being and economic development of the population without harming social equity and by respecting the environment. Water should be managed at watershed scale by involving all stakeholders (population, users, institutions, industrials, agricultures) according to participative and adaptive governance. The new paradigm implies the reorganisation of stakeholders that transects sectorial boundaries. It appears that the watershed seems the most relevant spatial area for integrated and sustainable water resource management. However, this spatial scale requires the preservation of natural resources from anthropogenic, economic and recreational activities.

For Grigg (1999), sustainable urban water management must be implemented according to a systemic approach with regard to local, regional and national contexts. Fane (2005) proposed a sustainable urban management method based on 5 principles that should be adapted to local contexts. The principles proposed are: i) water sensitive urban design; WSUD, ii) ecological sanitation, Eco-San; iii) ecological engineering, Eco-Eng, iv) advanced treatment; and v) soft water paths, SWP.

Many projects dealing with IWRM and urban water management have been carried out to improve knowledge on this issue and propose a framework for collaboration and improving practices by developing methods and tools. The NOVIWAM ${ }^{l}$ project (Noviwam, 2013) aims at promoting multilevel and interregional cooperation in the field of water management tools and methods. The aim of the SWITCH ${ }^{2}$ project (Switch 2013) is to find new solutions to increase the efficiency of urban water systems confronted by a range of global pressures. It is based on the

\footnotetext{
${ }^{1}$ The Novel Integrated Water Management Systems for Southern European Regions, from 2010 to 2013, the project was funded by the European Commission under call FP7-REGIONS-2009-1 "Regions of Knowledge" of the 7th Framework Programme for Research and Technological Development.

${ }^{2}$ Sustainable Water Management Improves the Health of Tomorrow's Cities, the project was funded by the European Community in the Framework 6 Programme from 2006 to 2011.
} 
rethinking of old paradigms and developing new solutions by improving scientific knowledge. The Swedish Foundation for Strategic Environmental Research, Mistra ${ }^{3}$ initiated a Swedish research programme called "Sustainable Urban Water Management" (Mistra 2013) to improve knowledge on sustainable water and wastewater management.

Several experts (CERTU, 2003; Chocat et al., 2007; Novotny \& Brown, 2007) recommended substituting the paradigm of urban sewerage by that of urban water management. This evolution concerns both technical infrastructures and organisations (municipalities, utilities, associations, enterprises, users, etc.) that participate in providing these services. Water produced and delivered in urban areas should be controlled integrally in urban design, organisation and management. It should be taken into account at catchment scale. This requires clearly defining interactions and modes of cooperation between the organisations and stakeholders involved at the scale of both the hydrological catchment area and the urban area. This goal can be reached if the assessment of the level of service provided by the system can be done objectively and used to help stakeholders to select the most efficient strategies. A large number of performance indicators have been developed to this end (Alegre, 2002; Balkema et al., 2002; Matos et al., 2003). Sustainable urban water management from the economic viewpoint implies covering operating costs and the capacity to finance the investment required. Taylor et al. (2008) outlined the importance of economic analysis for sustainable water management and the authors proposed a training manual that focuses on economic and financial instruments. Savic et al. (2008) highlighted the existence of financing shortfall across the whole water/wastewater sector, involving the operation and maintenance of existing infrastructures. It appears that the economic sustainability of the organisations and utilities composing the UWMS is a real challenge, which leads to the development of a costing framework based on whole life-cycle costing. The current research addresses part of this challenge by proposing an innovative and non-accounting approach for cost's assessment, tracking and explanation. Most of works and projects identified in the literature address the sustainability of water management through high level approaches or else focus on environmental and social issues. Economic analysis is used in a conventional accounting approach or according to whole life-cycle costing based on the aggregation of all operating costs on the one hand and all capital costs on the other hand. The originality of the work proposed here

\footnotetext{
${ }^{3}$ Project founded by the Swedish Foundation for Strategic Environmental Research from 1998 to 2006.
} 
consists of the development of a methodology that maps the subsystems composing the UWMS and through which economic and physical flows occur in order to better understand both the operation of the subsystem analysed and the cost drivers. It combines technical and economic analyses, by adapting three relevant approaches: i) the functional analysis highlights the relevant functions of the subsystem analysed, ii) the accounting based costing to assess the cost drivers, and iii) whole life-cycle costing to cover operating costs, capital costs and the dimension of time through the service life of sub-system infrastructures. The diversity of the services provided by the urban utility system and the multiplicity of the technical infrastructures required, complicate users' understanding of the costs borne (Cherqui et al. 2011). This knowledge is primordial for the elected representatives responsible for water who have to justify their public policies. Thus economic optimisation is a difficult problem to tackle, which is why the current methodology was developed for:

- Explaining the costs of an urban water management system: these correspond to the total cost of the service paid for and understood by the user. Costs can be broken down as a function of the activities that ensure the primary and secondary functions of the system, by identifying the associated assets and physical flows for each activity.

- Identifying the activities generating the highest costs: the goal of the owner is to obtain opinion and knowledge about costs impacting on activities, in order to optimize the processes of the system analysed.

- Assessing, by activity, the relationship between cost, the activity execution and the service provided. This evaluation allows: i) formulating an indicator that offers new understanding of the system by tackling its economic and technical dimensions; and ii) benchmarking the same activity against several equivalent systems deployed in different territories.

The present paper is divided into 5 main sections. After explaining the challenges and issues of understanding the urban water management system and the need to change paradigms in the first section, the second section focuses on the UWMS description and its boundaries .The third section presents existing methods for understanding physical systems and how they can be assessed by including the economic dimension. The fourth section describes the main steps of the 
implementation of the "Eco-EAR" methodology on a sewerage system. The last section describes the full-scale implementation of the method in the territory of a water management body in Alsace (France) and provides the main results.

\section{$2 \quad$ Urban Water Management System}

The urban water management system is considered as a virtual entity deployed within a geographical perimeter involving all natural water sources (groundwater, surface water, catchment area, rivers), treated water (irrigation and drinking water) and polluted water (industrial, domestic waste water) and all the infrastructures, assets, organisation and stakeholders involved in managing them directly and indirectly. Our definition is closer to that proposed by Hellström et al. (2000). For the authors, the UWMS is a combination of technical devices in a territory that can be summed up by: catchment and drinking water system, sewage network, treatment plants and stormwater system. The authors consider that the stakeholders and institutions are external to the UWMS but have a strong influence on it. The UWMS should be robust, flexible and adaptable to the local context (political, economic, environmental and social). Since water management is shared separately by several organisations and utilities, the UWMS should be defined as an assembly of subsystems, as shown in Figure 1. It highlights all the organisations, assets and stakeholders involved in water management at watershed level. The methodology proposed assumes that the total direct cost of the UWMS is the sum of all the direct costs of each subsystem. The current work focuses on the direct costs incurred in each subsystem, which can be qualified as internal costs as opposed to indirect and social costs that can be assessed based on externalities. The direct cost corresponds to a real operating or capital expense incurred by an organisation and assigned to a specific task, activity, resource or asset. The indirect cost or externality can correspond to a real expense or an impact assessment to measure the potential consequence of the system analysed on an external system or stakeholders. Figure 1 shows the possible externalities between the subsystems composing the UWMS. They describe potential positive (benefit) or negative (disadvantage) impacts which are not necessarily economic, due to the interactions between subsystems or with the environment. The boundary of the subsystem allows separating internal impacts from those that occur outside the subsystem boundary. Among involved subsystems, the developed approach focuses on wastewater systems and internal impacts assessed according to economic point of view through internal direct costs 
assessment.

Figure 1. UWMS boundaries and sub-systems

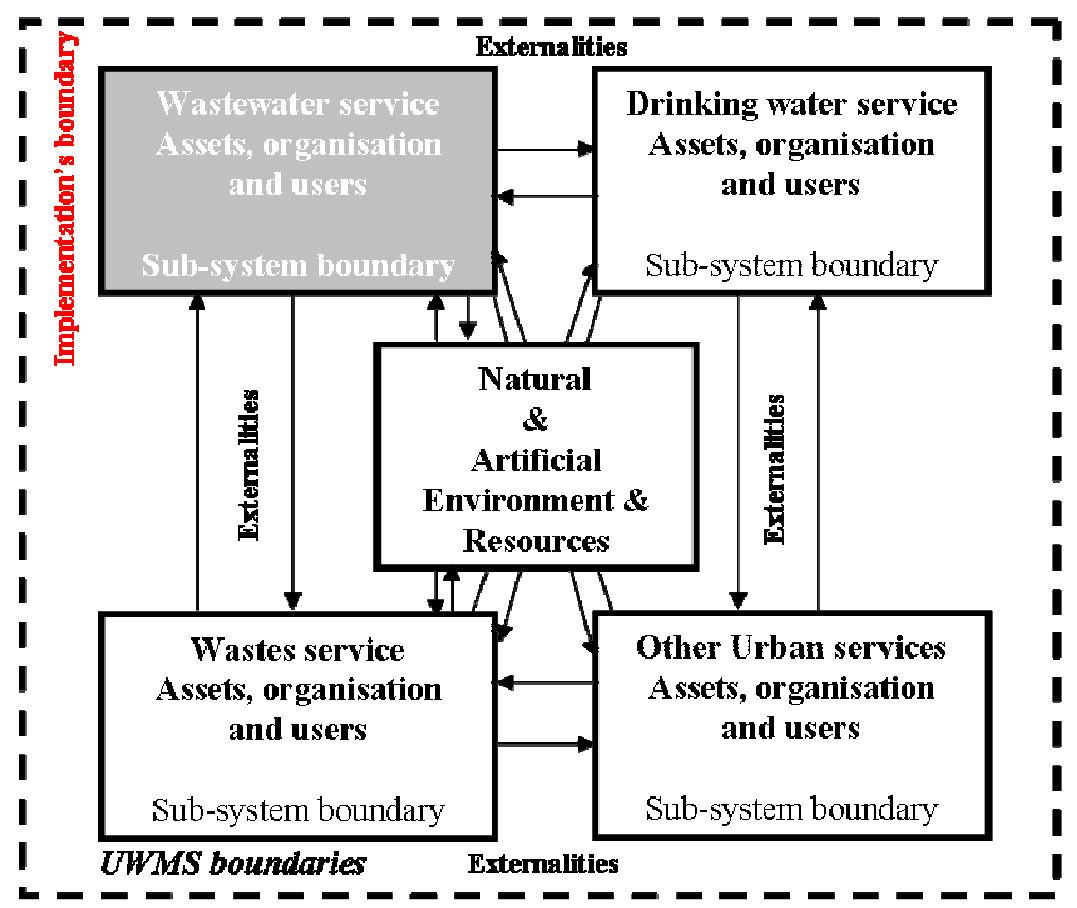

The purpose of the methodology developed, called "Eco-EAR", is to assess and break down the direct costs of a UWMS based on its component subsystems. The "Eco-EAR" methodology is similar to the "Evaluation-Action-Retroaction" (EAR) approach developed to assess all the services provided by an SUWM (Granger, 2009). The latter is based on the formulation of indicators "understandable" (by all the stakeholders) and the construction of causal trees. In this paper, the economic dimension is analysed by using "Eco-EAR" for the assessment of services rendered as a complement to the approach investigated by "EAR". The challenges are to quantify direct costs that indicate real expenditures, opportunities and benefits inherent to the delivery of the sewerage service. Indirect costs or externalities are not addressed in the current work; they are not necessarily economic, but possibly environmental or social. However the Cost-Opportunity- 
Benefit (COB) approach proposed is relevant to tackle both direct and indirect costs. It defines an algebraic measure that can be positive, which assesses the real or indirect expenditures to be borne by a third party, in our case the stakeholders of the system. The COB can also be negative and in this case indicates an opportunity or a benefit. It expresses one or several profitable impacts for the stakeholders that can be induced or avoided. This benefit can be measured for tangible and intangible assets, and it can indicate an exchange or use value. These measures constitute potentially understandable indicators and appear to be one of the possible improvements made by the method proposed. In order to address this aspect, a large number of significant works on the assessment of the cost-benefit of restoring natural systems, flood damage and sewer network dysfunctions were investigated (Dumax, 2009; Eleuterio et al., 2011; Werey et al., 2010).

In order to obtain initial feedback on the methodology developed and test it under real conditions, it is implemented in a limited area of the sub-system composed of technical infrastructures, an organisational entity and the most important stakeholders defining the wastewater system. It is characterised by the involvement of a variety of actors (owners, private companies, consumers, utility, elected representatives, private individuals, public and private institutions) which sometimes have conflicting interests. These interests must be reflected by one or several understandable indicators. Formulating understandable indicators leads to assessing the total cost of the sewerage service, including stormwater management by conventional techniques and also innovative alternative techniques (Bentarzi et al., 2012).

\section{Economic Assessment}

The interest of managers in economic assessment is not new, as mentioned in IEI (1998). Assessing the cost of the service provided and optimising the operation of infrastructures are considered as important factors for ensuring its sustainability. Fane \& Mitchell (2006) discussed existing practices for analysing the cost of water systems. The authors proposed 8 principles for best-costing practices for sustainable water systems, namely: i) system boundaries, ii) cost perspectives, iii) options analysis iv) net cost or benefit for options analysis, v) impact and externality analysis, vi) the time value of money, vii) uncertainty and precision, and viii) transparency in reporting. Three approaches used by the "Eco-EAR" methodology and in accordance with the above practices are presented in the following section. The first is based on 
the organisation's accounts by considering the budget as the main source of cost analysis. It recommends highlighting operating expenses (OPEX), capital expenditures (CAPEX) and combining them to assess a whole life-cycle cost based on a service lifetime step. The second approach is based on the description of a system according to a set of functions; each one is defined by one or several activities that are resource consumers. This breakdown is similar to that of "Activity Based Costing, ABC" explained in Chauvey \& Gérald (2004). The use of this method requires the implementation of analytic accounting in the organisation considered. The $\mathrm{ABC}$ method was first used in the 70s in manufacturing industries in order to track costs and reduce production costs. Nowadays, it is widely used in order to track the cost drivers of a product or service. The method analyses a system by highlighting activities impacting on costs and checking whether they create added value or not. Thus, beyond cost analysis, the "ABC" method is aimed at eliminating unnecessary activities with low added-value to better control costs. The method is based on the following assumption: the cost generated by one or more activities is inherent to the consumption of resources. The $\mathrm{ABC}$ method seems an interesting complementary alternative to the classical accounting approach. Its implementation for water systems is relevant, as mentioned in Matthews et al. (2009) where the authors develop a high level model to quantify the real costs of delivering water services in rural areas. Another assessment approach is based on the estimation of whole life costs by breaking down a system according to its assets and matching operating and capital costs within spatiotemporal boundaries defined for the system analysed. This approach is described in ISO (2008). Cost estimation is based on the "Life Cycle Costing Analysis, LCCA" (Skipworth, 2002) method which distinguishes three main phases in an asset's life, namely, the building or construction phase, the operating phase and the end-of-life phase. Three types of cost should be assessed: investment costs or capital costs (CAPEX), operating costs or expenses (OPEX) and removal or deconstruction costs. Similarly, Savic et al. (2008) present the development of Whole Life Costing (WLC) for the capital and operational management of water and wastewater systems based on global performance analysis and explicit linking between costs and their drivers. (Lim et al., 2009) developed an optimization model to optimize the life cycle cost for a waste water treatment network. The authors outlined the need to achieve trade-offs between the costs incurred throughout life cycle steps, such as construction, operation, maintenance (OM), and disposal. Vouk et al. (2011) proposed the use of a neural network for the economic analysis of wastewater 
systems based on the life cycle approach. The authors outlined the use of mapping tool as a neural network for technical analysis, but observed the absence of auxiliary tools for economic analysis. According to the review of the literature and feedback from the experiment, the development of the "Eco-EAR" method improves on "EAR", in order to satisfy three essential points: i) the need to adapt the EAR methodology to establish causalities between the main activities of urban water systems and the cost incurred by describing the system with a relevant mapping approach inspired by functional analysis; ii) the need to improve the "EAR" approach by combining it with the "ABC" approach which identifies cost driver activities; and iii) the need to assess the whole life cycle of the system and its components as they represent major fixed assets from the accounting standpoint, as recommended in Matos et al. (2003). Kraemer et al. (2004) highlighted the existence of two levels for the economic analysis: i) the individual level, meaning user, client or citizen; and ii) the system level, meaning aggregations of individuals and organisations. The review of the literature allowed identifying a non-exhaustive list of economic assessment methods that could be applied to tangible and intangible assets or to evaluate non market services or goods in the catchment area. These methods are often used to measure impact or benefit, externalities and non market values. The following methods appear relevant: Cost Benefit Analysis (CBA), Contingent Valuation Method (CVM), Travel Cost Method (TCM), Hedonic price (HP). This dimension is not addressed in the current research but constitutes a relevant improvement that should be addressed in further work.

\section{4 “Eco-Ear” Methodology}

The implementation of the "Eco-Ear" methodology proposed (Figure 2) is mainly based on the identification of the key activities that characterise the primary and secondary functions of each subsystem of the urban water management system (UWMS) according to a functional analysis approach. It consists of mapping each subsystem, by highlighting links between activities that ensure the functions of the subsystem analysed. These activities represent the main cost drivers. "Eco-Ear" requires that asset elements be clearly distinguished from the organisations representing the entities which manage the subsystem. The identification of the main activities that characterize the system is inspired by the "ABC" approach. These key activities represent the knowhow and main skills of the management organisations mobilised to satisfy the users. Therefore the first step of the method encompasses 3 types of flow: i) the reference flow that 
indicates the main function of the system analysed; ii) the physical flows that correspond to real flows of materials, energy, the resources consumed for the operation, renewal, maintenance and the extension of the system; and iii) economic and financial data and information that permit assessing the direct costs of the resources consumed. "Eco-EAR" superimposes mapped flows and describes links with activities that characterise the system, in order to establish causalities and inherent effects between flows on the one hand, and between activities on the other hand. It highlights the interfaces between activities and shared flows. This step leads to the definition of the first level for aggregating physical and economic flows into two main items: i) flows due to assets, and ii) flows due to the organisation as an entity that manages the system.

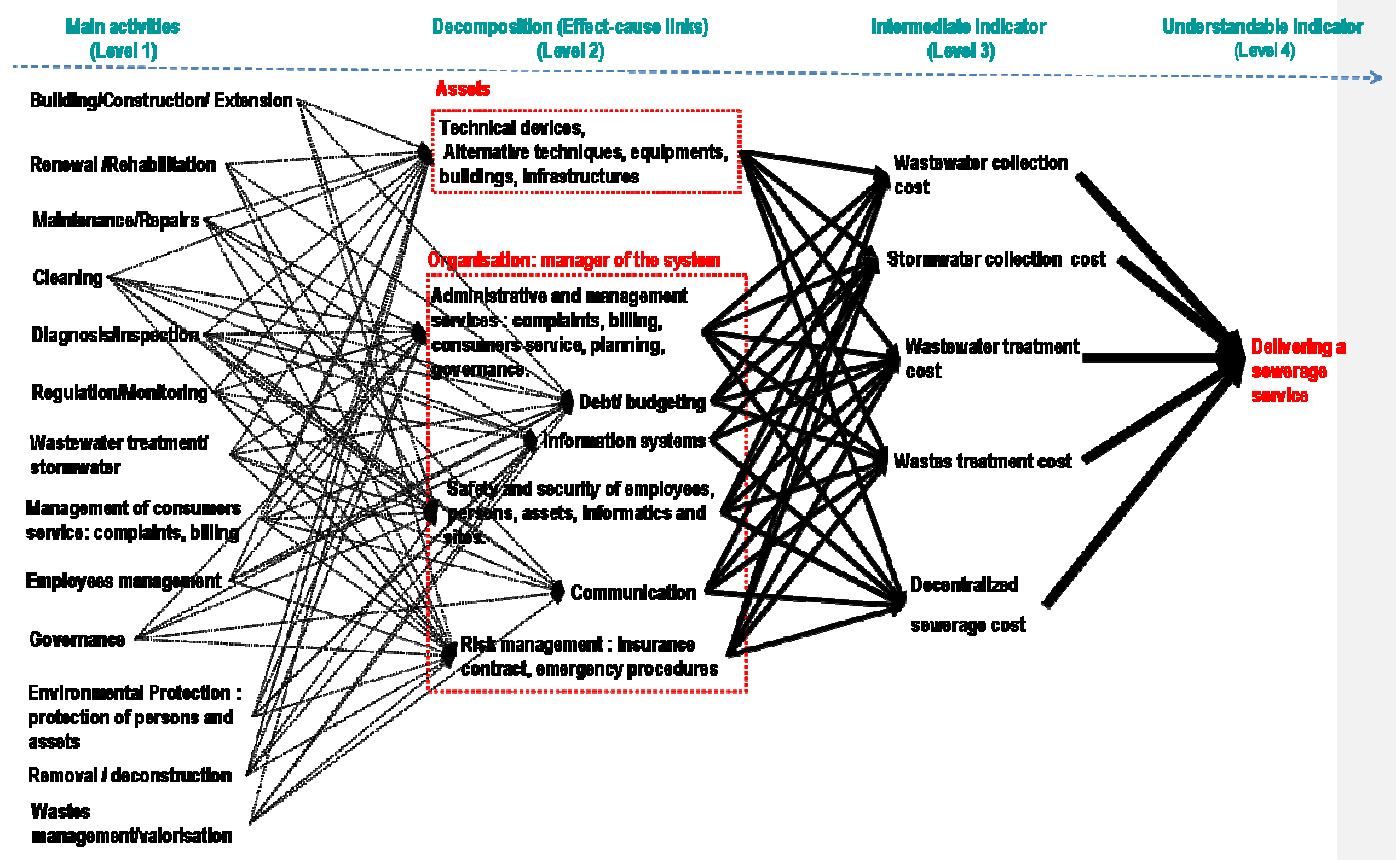

Figure 12. Figure 2. "Eco-EAR" method

In its current version "Eco-EAR" analyses a specific subsystem or compartment of the UWMS, namely the wastewater and stormwater systems. The method considers UWMS as an artificial entity deployed within a geographical territory with borders and which involves a number of assets, organisations and stakeholders that contribute directly and indirectly to urban water management. To fulfil the functions expected, each sub-system implies different kinds of flows:

Mis en forme : Anglais (États Unis) Code de champ modifié Mis en forme : Anglais (États Unis) 
materials, energy, resources, products, wastes and emissions. Among these flows, it is necessary to select the flow that best represents the primary function of the system analysed. The selection and use of a reference flow is based on the functional analysis method (AFNOR, 2011). The functional analysis is thus implemented for a system delimited by spatial boundaries and designed to ensure a primary function, the latter being assessed by the reference flow. Generally, the system ensures secondary functions; these functions can also be assessed using other flows. The reference flow also allows characterising the system analysed and benchmarking it with other equivalent systems. Concerning the wastewater subsystem, the primary function retained is the sewerage service delivered to users, which will be used to define an understandable indicator: "the direct cost of the sewerage service". The sewerage service is delivered by the wastewater system with boundaries defined by the organisation (administrative and management services) and infrastructure assets (network, pumps, treatment plants). This primary function involves 5 secondary functions: i) wastewater collection, ii) stormwater collection, iii) decentralised sewerage, iv) wastewater treatment, and v) waste management (sludge recovery and waste incineration). Several input or output flows can be selected as the reference flow, such as the population equivalent concerned by the service, the volume of effluents, the size or length of the system, and the quantity of sludge's generated by the system. Regarding the UWMS system, the selected reference flow is the volume of output effluent of the wastewater system. This flow is composed by the volume of wastewater generated by potable water consumption on the one hand, and by stormwater and sewer infiltration transported by the pipe network on the other hand. This case characterizes the system with the combined collection of effluents. The Table 1 summarises the main information concerning the primary and secondary functions of the wastewater subsystem.

Table 1. Description of the sub-system analysed 


\begin{tabular}{|c|c|c|c|c|}
\hline Sub-system & Boundaries & Primary function & Reference flow & Secondary functions \\
\hline $\begin{array}{l}\text { Wastewater } \\
\text { system (waste } \\
\text { water and storm } \\
\text { water flow) }\end{array}$ & $\begin{array}{l}\text { Organisation and } \\
\text { infrastructure : utility, } \\
\text { administrative } \\
\text { services and assets }\end{array}$ & $\begin{array}{l}\text { Delivering a sewerage } \\
\text { service }\end{array}$ & $\begin{array}{l}\text { Annual volume of } \\
\text { flows (waste water, } \\
\text { storm water and } \\
\text { parasite water) } \\
\text { crossing the } \\
\text { wastewater system }\end{array}$ & $\begin{array}{l}\text { - Waste water collection } \\
\text { - Stormwater collection } \\
\text { - Decentralized } \\
\text { sewerage } \\
\text { - Waste water treatment } \\
\text { - Wastes management } \\
\text { (sludge recovery and } \\
\text { wastes incineration) }\end{array}$ \\
\hline
\end{tabular}

Wastewater and stormwater can be distinguished easily when the subsystems are equipped with separate pipe networks for effluent transport. This situation is different from the first one because the volume of effluent transported is lower. Indeed, the existence of two separate networks decreases pressure on treatment plants because they receive lower volumes for treatment. The existence of separate networks can lead to taking into account two reference flows to characterize the system: i) the volume of wastewater, and ii) the volume of stormwater, respectively. All the flows flowing through the system have to be linked with the primary flow. They are identified and assessed during an accounting year, i.e. a calendar year. Flows corresponding to capital investment are levelled out over the service life of the assets concerned. Depending on the accuracy of data and their availability, it is possible to estimate the annual effort of investment via the depreciation of each component of the asset, modified by the financial interests generated by current debt and by considering other financial depreciations due to previous loans. The aggregation of all these expenditures allows estimating annual investment expenditures, as recommended by Matos et al. (2003). The value obtained constitutes a relevant estimation of annual capital expenditures according to the whole life cycle costing approach as it involves the asset's service life. The expected asset service life (useful period) value can be estimated according to the recommendations of public sector accounting standards board (PSASB) dedicated to tangible capital assets (TCA) (FRS 1999, DGCL 2004, CICA 2007, IFRS 2012,

AASB 2013). The depreciated amounts are referenced in the accounting documents of the organisations involved (asset owner) and can be measured for each asset of the system. The following sections focus on the direct costs generated by providing the wastewater and stormwater management service. Finally, mapping the different flows flowing through the system makes it possible to highlight the links between the functions ensured (primary and secondary), 
asset infrastructures, the organisation and activities. "Eco-EAR" is divided into 4 levels of analysis which are described below.

\subsection{Matching key activities (Level 1)}

The aim of this level is to match key activities by drawing up an exhaustive list of activities that contribute directly or indirectly to ensuring the required level of service. The current development focuses on a combined system (one including a wastewater and stormwater sewer). The key activities of the system can be established according to both a primary function and secondary functions. Based on the functions to be ensured by the wastewater system, the activities that appear relevant are the following: construction/extension, rehabilitation/renewal, maintenance/repairs, cleaning, diagnosis/inspection, regulation/monitoring, wastewater and stormwater treatment, consumer service, management/governance, environmental protection, protection of persons, protection of assets, waste management/recycling and removal/ deconstruction.

For each matched activity, it is necessary to establish an exhaustive list of tasks required, the resources consumed and all the assets needed to perform the activity concerned. This description must highlight the physical flows that characterise the activity and all the technical characteristics of the operation and dedicated assets. This step is based on 3 main phases:

i) identification of the flow types consumed or generated; ii) flow assessment: quantity, volume or density; and iii) the economic assessment of each matched flow. The last phase may be difficult as it requires gaining access to financial data and because of the uncertainty or incompleteness of data. Indeed, the economic assessment depends on the allocation of the cost flow. When the approach uses global accounting data, this leads to a loss of accuracy since the data are only available at upper management level, thereby reducing the accuracy of the results. The reliability of the results obtained is correlated to the availability of accurate financial and economic data. However, to mitigate this aspect the follow up of "ABC" approach for cost assessment is recommended. It requires a detailed description of physical flows, though it is difficult to measure and level out all the economic flows over an annual operating cycle. According to the "ABC" approach, each activity can be broken down into a set of tasks. Each 
task consumes resources that correspond to physical flows that must be matched. Each resource is characterized by a driver that indicates the amount consumed (quantity or volume).

The cost of the activity will be calculated by assessing the cost drivers of the resources consumed. Each activity is characterised by a driver, noted activity driver. This allows clearer understanding of the resources used by the activity to satisfy users. All the drivers (resource-task) must be assessed economically to estimate the cost of the activity. The cost driver of the activity is obtained by aggregating all the cost drivers of the tasks, which are obtained by aggregating the resource cost drivers.

Although this breakdown is relevant and desirable, it is not always feasible. In the context of lack of data, cost drivers can be estimated according to an elicitation process of "allocation keys" or "apportionment ratios". The estimation can be made by experts and professionals, from experience, or be based on a physical relation such as flow distribution. Table 2 provides different ways of dealing with the problem of cost assessment, by considering the constraint of availability or lack of economic and financial data.

When analytical accounting is not implemented, the legal accounting documents available from each stakeholder participating in delivering the sewerage service are considered as our main data source. These documents are: administrative accounts (in the case of public accounting), income statement and balance sheet (in the case of private accounting). The data contained in accounting documents have to be cross-checked with operating data in order to match physical flows with economic and financial flows. This leads to allocating expenditures according to apportionment ratios. Three possible situations are encountered: 1) Economic assessment of physical flows, 2) Partial economic assessment of physical flows, and 3) Economic estimation of physical flows. 
Table 2. Approaches for the economic assessment of physical flows

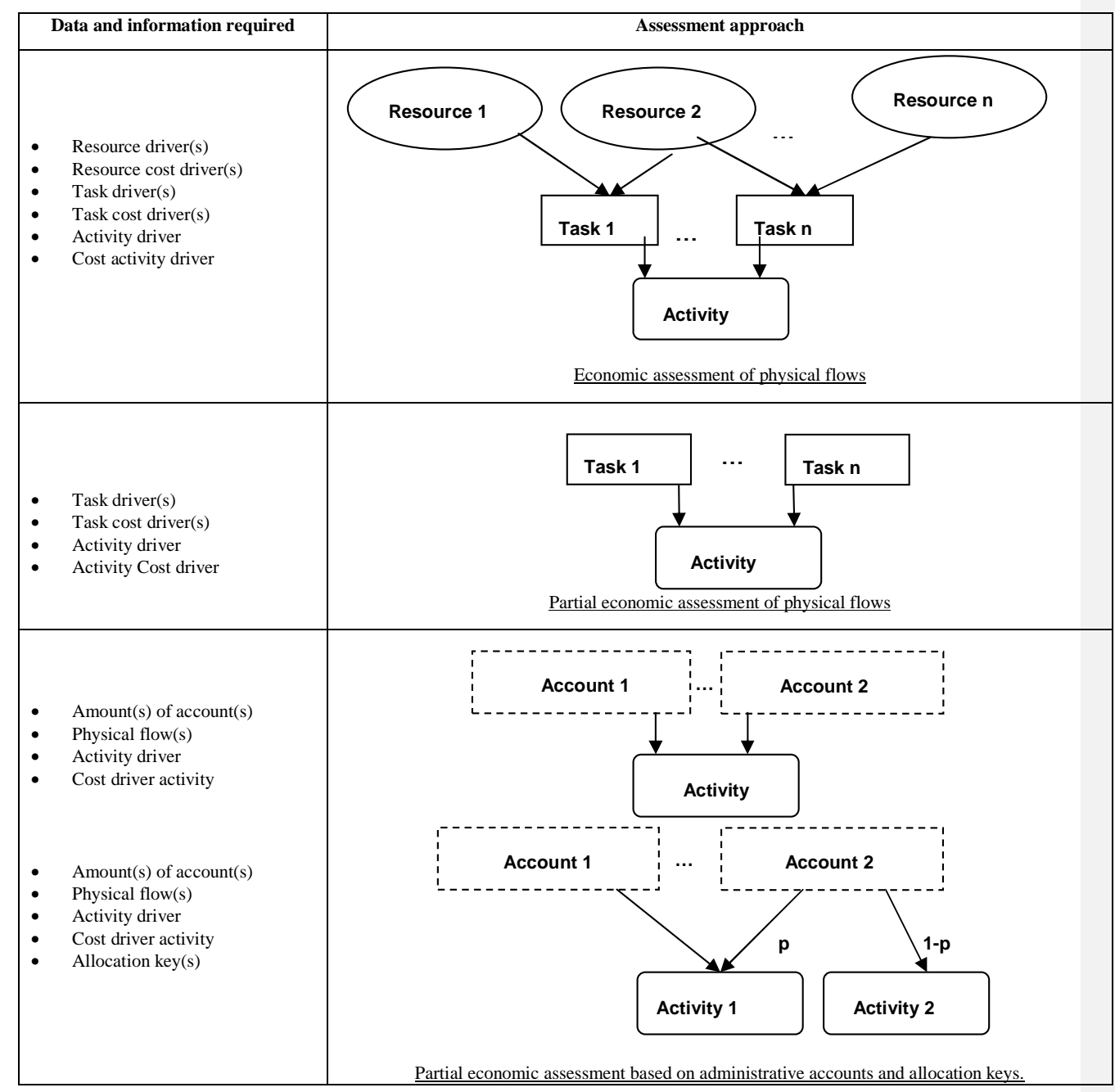




\subsection{Aggregation items: asset and organisation (Level 2)}

This step allows aggregating the flows generated by the activities of "Level 1" into two main items: "tangible assets" and "the organisation" as an entity that manages the system. Indeed, two dimensions must be taken into account in order to reach the required level of service: i) the reliability of technical facilities and assets, and ii) ensuring the efficient operation of the assets through the efficient management of the utility. The "asset" item concerns technical components, equipment, machines, pumps and urban development inherent to alternative techniques that can be visible or invisible. This item groups all the fixed assets in the accounts of the organisation concerned by the management of wastewater and stormwater. Sorting the assets should be done according to their main function: i) assets dedicated to the collection and transport of effluents, mainly composed of drains, pipes, pumps and basins; and ii) assets dedicated to treating and recycling wastewater such as treatment plants and sludge treatment installations. The item "Organisation" groups management and administrative services. It concerns consumer services (i.e. complaints, billing), information system management, budgeting, human resource management, employee and personal safety, protection of property, and risk externalisation through insurance policies. Service contracts and all services provided by external enterprises are also involved in this item. This particular situation highlights real practices that concern the involvement of other stakeholders in performing certain activities. Because activities have been externalised, they are taken into account by the utility only by their cost drivers. The details of the resources consumed and task cost drivers are not systematically provided, so it can be difficult to describe all the flows and establish a clear map of them, in order to establish cost mapping. In this specific case, the economic assessment is partial; it depends on the data and information made available by the service provider.

\subsection{Intermediate indicator assessment (Level 3)}

This level aggregates the output flows from the items of "Level 2" into 6 intermediate indicators that offer an initial description of the cost breakdown of the sewerage service. The breakdown is based on the secondary functions of the sewerage system, as shown in Table 1.centralised The following intermediate cost indicators can be assessed: i) wastewater collection cost, ii) stormwater collection cost, iii) wastewater treatment cost, iv) waste treatment and recycling costs, 
v) decentralised sewerage cost, and vi) associated costs that group all the expenditures not imputable to the identified secondary functions.

Two types of indicators can be deduced at this level: i) the annual cost to ensure each secondary function, and ii) the cost driver of each secondary function, which is a proportional cost obtained by calculating the ratio between the cost of the secondary function and its reference flow. Both indicators are relevant and contribute to better understanding of the cost tracking and the items of expenditure of the system analysed.

\subsection{Understandable indicator assessment (Level 4)}

Level 4 allows assessing the cost of the services provided by the wastewater system. It represents the highest level of cost aggregation according to the "Eco-EAR" method. The understandable indicator obtained can be measured by an annual time step with an absolute value that indicates the whole cost for the service provided. It can also be measured as a ratio by dividing the whole cost by the reference flow of the wastewater system. Implementing the "Eco-EAR" methodology highlights a cascade of interactions from level 1 to level 4. It allows obtaining a map of flows between activities, assets, organisations and functions rendered. Links can have several flow formats: economic, financial and physical. From the economic point of view, direct costs are matched and aggregated as they rise from the lowest level (Level 1) to the highest one (Level 4). In the case of missing data or the impossibility of allocating tasks to specific activities, unexplained expenditures should be assigned to the associated costs.

\section{$5 \quad$ Case study}

The purpose of the "Eco-EAR" method is to describe the direct cost structure of a subsystem of a UWMS by focusing on the sewerage service system in a specific territory, where: i) several competencies are shared, and ii) several stakeholders coexist in order to ensure the required level of service. The organisations providing the services are: i) the SIVOM (SIVOM, 2011), i.e. the multipurpose joint board of local authorities (the owner and manager in the sub-territory); ii) the "Lyonnaise des Eaux, LdE" (network manager); and iii) Veolia (wastewater treatment plant manager). This full-scale application aims at: 1) testing and improving the "Eco-EAR" methodology, by highlighting the difficulties encountered during its implementation and identifying possible improvements; 2) assessing understandable indicators of service cost that 
allow cost tracking in order to identify the activities with the highest cost impacts and potential cost reduction margins; and 3) generating knowledge for the wastewater system owners by providing innovative indicators that combine both technical and economic dimensions. This approach can be also used to benchmark equivalent wastewater systems. In the following sections the characteristics of the territory studied, the implementation of "Eco-EAR" method and the main results are presented.

\subsection{The system studied}

The territory studied involves the SIVOM of the Mulhouse Region. It includes 25 municipalities of the greater urban area of Mulhouse and the mixed organisation of sewerage of the "Basse Vallée de la Doller". Regarding urban water management, the joint board (SIVOM) ensures the following missions: wastewater and stormwater collection, wastewater treatment and decentralised sewerage. It serves about 240,000 inhabitants. The boundary of Greater Mulhouse encompasses seven sewerage sub-systems, namely: 1) "Potassique", 2) Turgot, 3) Vauban, 4) Four Seasons, 5) industrial area, 6) Rixheim, and 7) Illzach. The sewerage system has a total length of $1,760 \mathrm{~km}, 95 \%$ of which is composed of combined sewer pipes. The annual volume of drinking water billed is about 11 million $\mathrm{m}^{3}$. The SIVOM has 5 wastewater treatment plants that treat around 20 million $\mathrm{m}^{3}$ of effluents, mainly composed of wastewater, stormwater and sewer infiltration.

The territory is divided into two main urban areas: 1) the "Potassique" sewerage sub-system gathers 9 municipalities ${ }^{2}$ for which the "SIVOM" has all the competences and sewerage services, and 2) 16 municipalities ${ }^{4}$ of the greater urban area of Mulhouse whose urban water management has been entrusted to "LdE" by virtue of a leasing contract The last stakeholder, Veolia, manages wastewater treatment plants. In brief, the system studied to implement "Eco-EAR" consists of a concatenation of sewerage networks, arrays of technical devices and wastewater treatment plants. It should be noted that the assessment of the direct cost of the sewerage service was carried out exclusively for the "Potassique" sub-system (the part managed by the SIVOM). The part managed by "LdE" will not be discussed in this paper. The estimation obtained of direct cost is

\footnotetext{
${ }^{4}$ Didenheim, Lutterbach, Morschwiller le bas, Mulhouse, Reiningue, Zillisheim, Brunstatt, Illzach, Eschentzwiller, Flaxlanden, Pfastatt, Riedisheim, Zimmersheim, Habsheim, Rixheim, Sausheim.
} 
partial and explains only a part of the whole cost for the sewerage service delivered to the entire territory. Figure 3 shows the map of each stakeholder's deployment in the territory analysed.
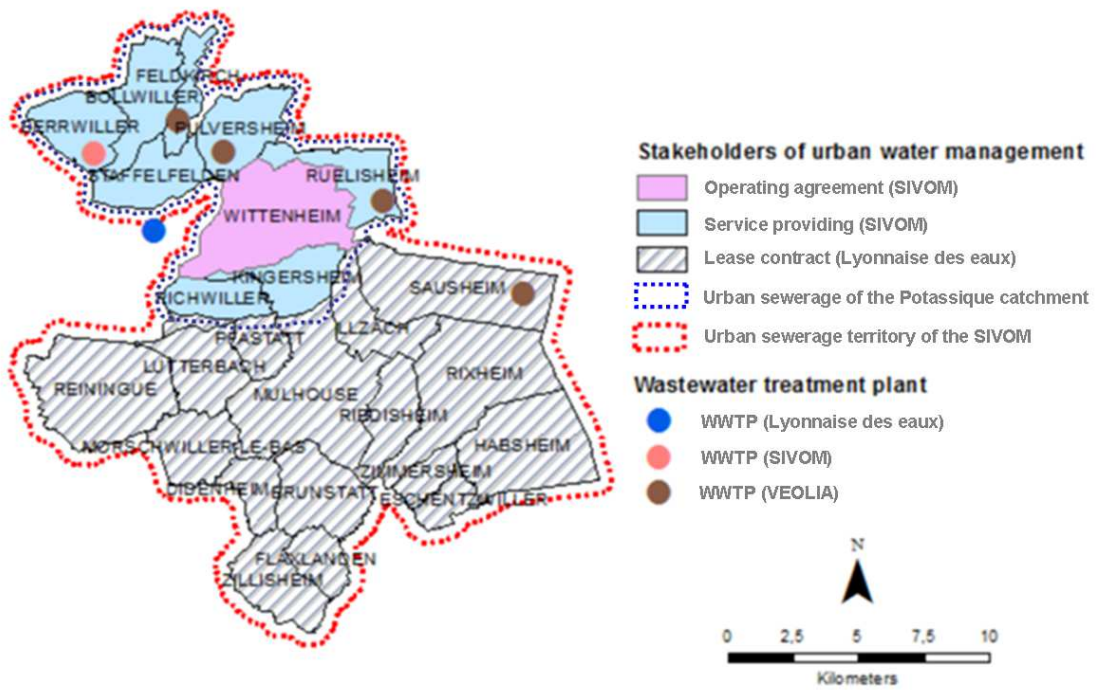

Figure 3. Deployment map of stakeholders in the territory

\subsection{Implementation}

The primary function chosen for the subsystem analysed is that of maintaining the sewerage service sustainably. This implies taking into account the following secondary functions: wastewater and stormwater collection, decentralised sewerage, wastewater treatment, waste treatment and recycling. The reference flow selected to describe the primary function is the annual volume of effluents collected and treated at the treatment plants. This choice is justified by the fact that the network studied is a combined sewerage system (wastewater and stormwater). This flow is estimated at 27.7 million $\mathrm{m}^{3}, 22.3$ million $\mathrm{m}^{3}(80 \%)$ passes through the LdE territory and 5.4 million $\mathrm{m}^{3}(20 \%)$ involve the "Potassique" sub-system territory. In this case the annual water flows comprise: i) the volume of drinking water billed, ii) the volume of stormwater and iii) the volume of sewer infiltration. Therefore the annual volume of drinking water represents about $57 \%$ of the average annual volume passing through the sewerage network. To facilitate the 
implementation of "Eco-EAR" method, the "Ecoval ${ }^{\circledR}$ " mapping software ${ }^{5}$ for process evaluation was used. It enables establishing three types of system mapping: 1) physical flow mapping, 2) cost formation mapping, and 3) cost driver mapping. Figure 4 illustrates the implementation of the "Eco-EAR" method by browsing through the four main levels of analysis for the "Cleaning" activity in the "Potassique"sub-system.

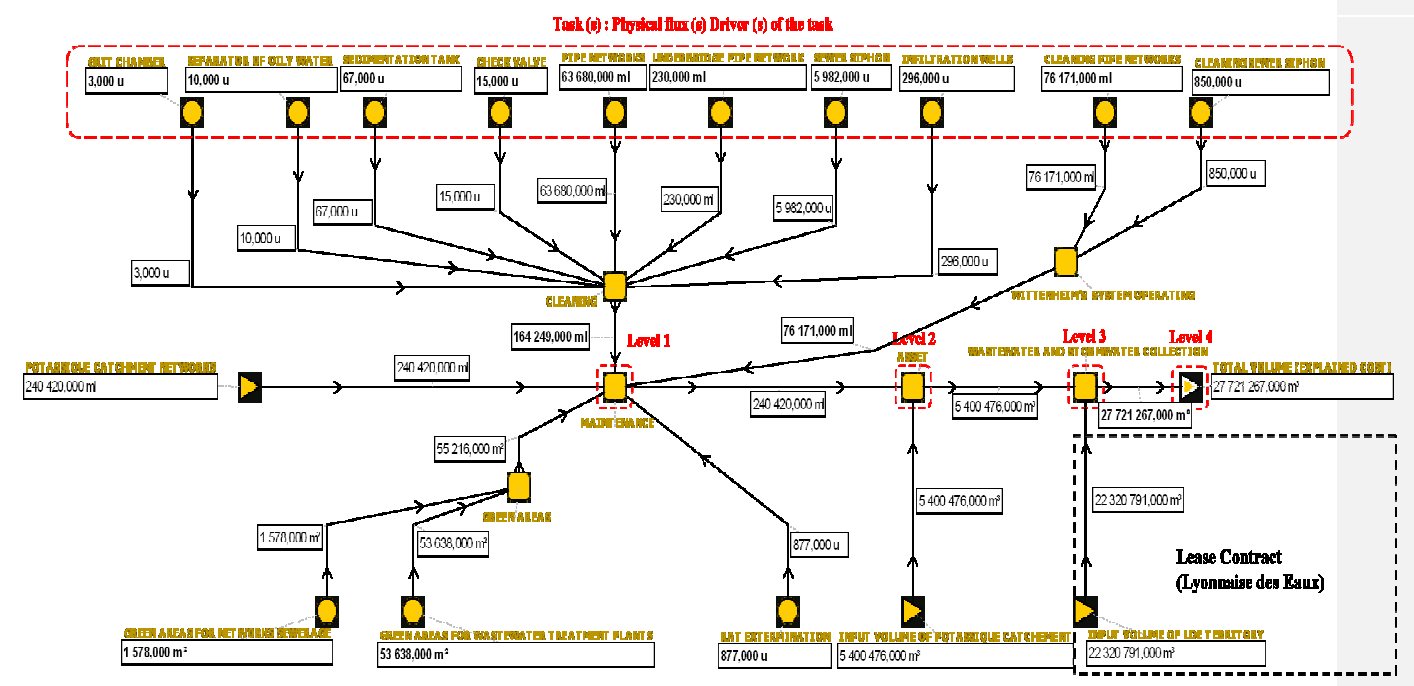

Figure 4. Physical flow mapping of the "Cleaning" activity

The mapping shown in Figure 4 illustrates the physical annual flow (year 2011) of the "Cleaning" activity in a sub-territory managed by the SIVOM. It shows the 4 levels of analysis of the "Eco-EAR" method. The first level (Level 1) provides data and information on all the tasks composing the activity selected. For each task driver (cleaning of infiltration wells, pipe cleaning, and sewer siphon cleaning, etc.) the type and amount of physical flows are measured. The second level of analysis (Level 2) deals with the network asset. In this case the driver is the total length of the network deployed in the "Potassique" sub-system. The third level (Level 3) assesses the impact of the secondary function "wastewater and stormwater collection" on the sub-system for which we consider the reference flow as the annual volume of effluents equal to approximately 5.4 million $\mathrm{m}^{3}$. The last level shows the method used to aggregate all the flows of the previous

\footnotetext{
${ }^{5}$ www.ecoval.fr
} 
levels and measure the contribution of the "Cleaning" activity in the sub-system considered to the entire area within the boundary of the subsystem.

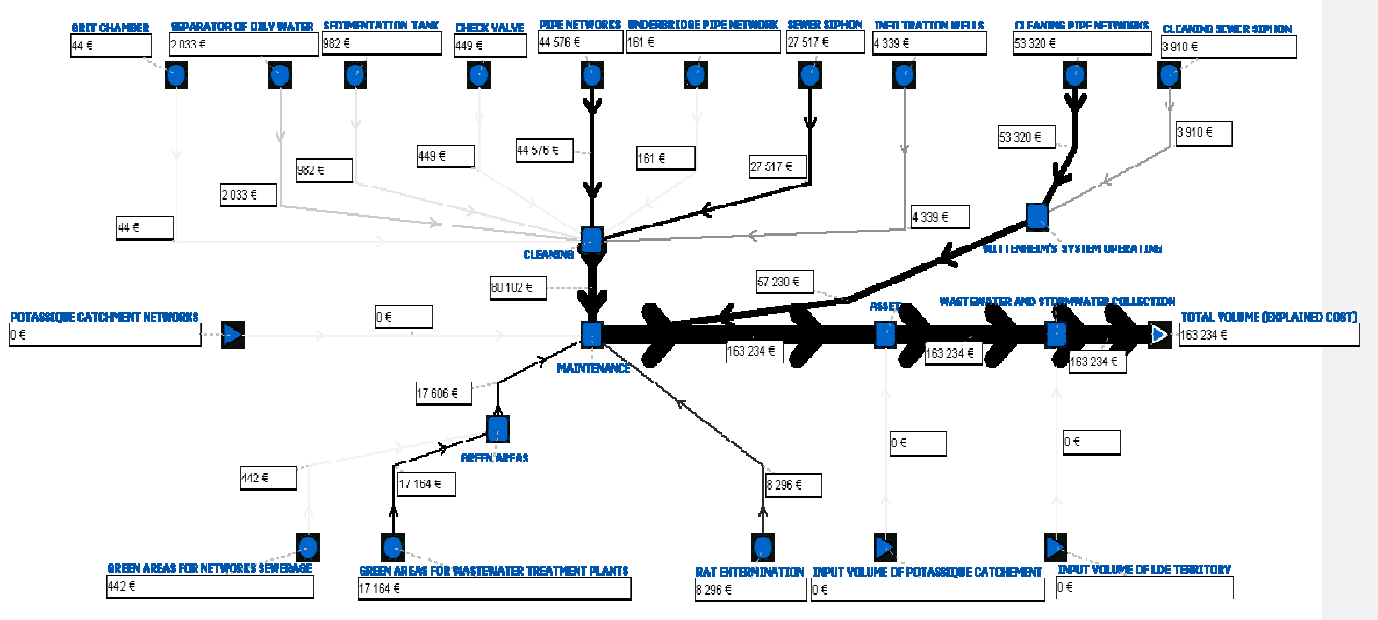

Figure 5. Economical flow mapping of the "Cleaning" activity

Figure 5 illustrates the second layer of flow mapping related to the economic assessment of the physical flows identified in the previous map. The map shown was obtained by crossing the quantity of physical flows with the cost drivers of resources and tasks. As shown in Figure 5, the cost structure of the cleaning activity depends to a large extent on the task of pipe network cleaning: it represents $60 \%$ of the total cost of the activity (56\% of network cleaning costs are for the pipe network and $35 \%$ for the sewer siphon). The second cost item is the maintenance of green spaces (in urban areas and around treatment plants) which represents $32 \%$ of the total annual cost. The total annual cost of this activity is about $€ 163,234$. As shown on the map, this amount is allocated to several tasks and explained accurately to highlight the main items of expenditure. It sorts the tasks with the highest impact on costs, namely asset cleaning and green space maintenance. 


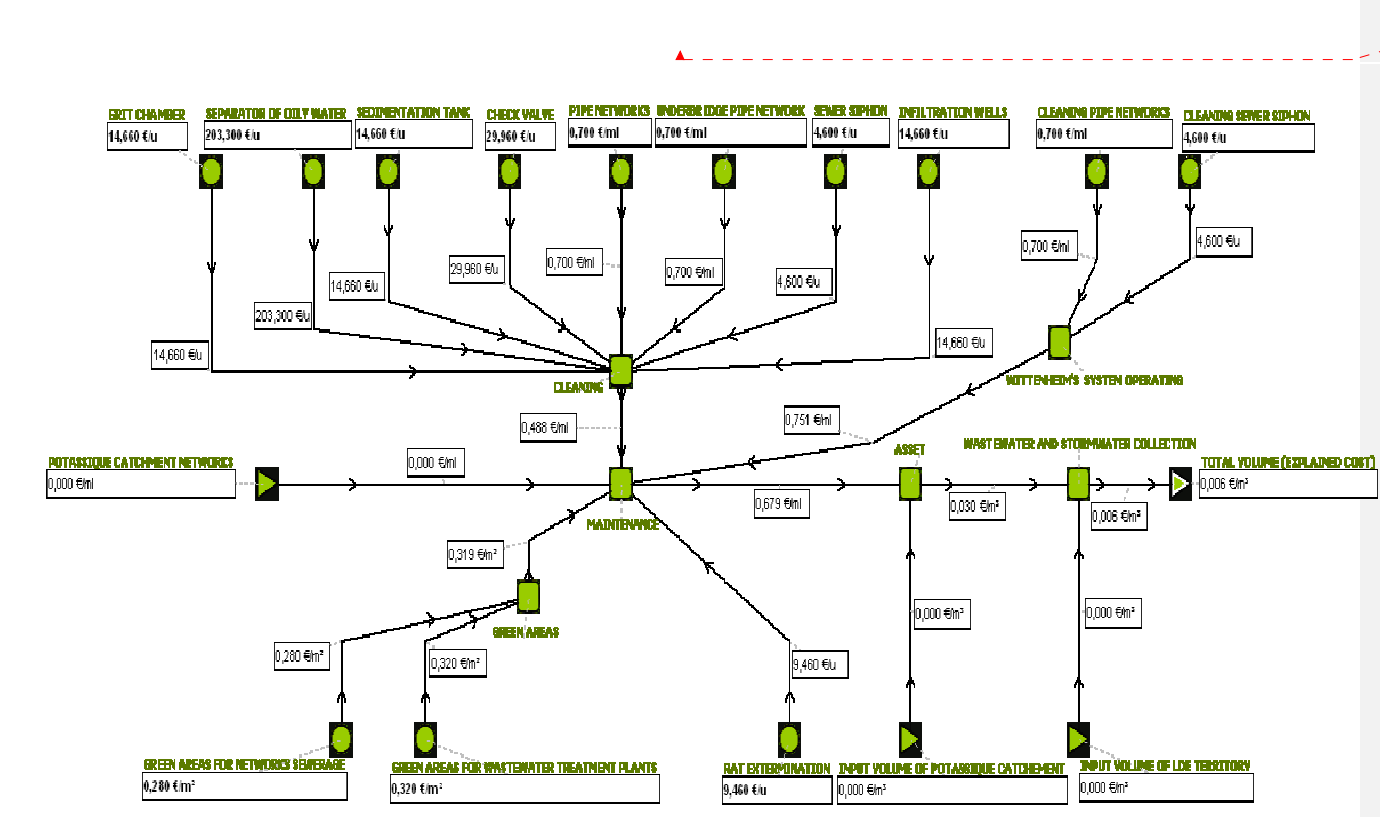

Figure 6. Map of cost drivers for all analysis levels

Superimposing the two previous maps allows assessing the cost driver of the activity and all the related task cost drivers at each level of analysis, as shown in Figure 6. Therefore the ratio obtained expresses a cost per unit of physical flow considered. It represents a mean annual value per unit of flow. For example, the mean cost of green space maintenance is $€ 0.319 / \mathrm{m}^{2}$. Analysis of the map shows that the "cleaning" activity contributes $€ 0.03$ per $\mathrm{m}^{3}$ to the secondary activity "wastewater and stormwater collection" (level 3). Another interesting result concerns the contribution of this activity in the sub-system considered to the cost of the sewerage service, by involving the entire system. This contribution amounts to $€ 0.006 \mathrm{per}^{3}$. The mapping approach was implemented for all the matched activities. Two kinds of results were obtained: 1) physical flow mapping, and 2) assessment indicators. Table 3 shows the relevant results for certain activities.

Table 3. The results of indicators calculated on the basis of a reference flow corresponding to the volume characterising each territory. 


\begin{tabular}{|c|c|c|c|c|c|c|c|c|c|}
\hline \multirow[b]{2}{*}{ Actirijes } & \multirow{2}{*}{ 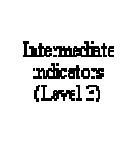 } & \multirow{2}{*}{$\begin{array}{l}\text { Contrilution } \\
\text { in the cכe of } \\
\text { sorruse } \\
\text { sterite }\end{array}$} & \multirow{2}{*}{$\begin{array}{l}\text { Uhiespten } \\
\text { duble } \\
\text { inclisator } \\
\text { (Lesel 4) }\end{array}$} & \multicolumn{2}{|c|}{ Mesmeost } & \multicolumn{4}{|c|}{ Contributian } \\
\hline & & & & $\begin{array}{l}\text { Uhan semproge } \\
\text { of Tetaseifue } \\
\text { Luthrtur }\end{array}$ & $\begin{array}{l}\text { Uwhan } \\
\text { serperage } \\
\text { teritary of the } \\
\text { sTon }\end{array}$ & $\begin{array}{l}\text { Uban: } \\
\text { Totosei } \\
\text { Lalthru }\end{array}$ & $\begin{array}{l}\text { II } \\
\text { il }\end{array}$ & $\begin{array}{l}\text { Utban: } \\
\text { tolution } \\
\text { STFol }\end{array}$ & of the \\
\hline $\begin{array}{c}\text { Feveral/Rehabittadion/5üdinghax } \\
\text { encicn }\end{array}$ & $0.006 \mathrm{hm}^{3}$ & $6,31 \%$ & \multirow{7}{*}{$n \Delta * 6 \in f_{m}{ }^{3}$} & \multirow{7}{*}{ n nfims } & \multirow{7}{*}{$0.0 \mathrm{me} \mathrm{m}^{3}$} & Explained & Uneplined & Explimed & Urexploned \\
\hline Cleanne & $0.006 \mathrm{~m}^{1+*}$ & $3,55 \%$ & & & & \multirow{6}{*}{$932 \%$} & \multirow{6}{*}{$68 \%$} & \multirow{6}{*}{57 .t. } & \multirow{6}{*}{$42 * n$} \\
\hline Mauterancerpepanaton & UUJ4AEimr ** & U, $54 \%$ & & & & & & & \\
\hline Llegandal' Inspectim & $0.0036 \operatorname{tmon}^{3}+$ & $0,58 \%$ & & & & & & & \\
\hline Treatnest: wostewnter stormwoten & $0251 \mathrm{en}^{3} \cdot$ & $31,75 \%$ & & & & & & & \\
\hline Farted Mamagment & $0.0895 \cos ^{3}$ & $10,80 \%$ & & & & & & & \\
\hline 7.rphingnes muntopment & n $19 / 9 \mathrm{~m}^{3}{ }^{3}$ & $2,31 \%$ & & & & & & & \\
\hline
\end{tabular}

"Urteanseperese lemitory of the SIVDM.

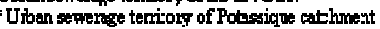

The aggregation of these indicators allows evaluating understandable indicators that reflect the value of the average sewerage service cost in the "Potassique" sub-system territory, whose mean value is equal to $€ 0.466$ per $\mathrm{m}^{3}$. This assessment is partial because it explains $93.2 \%$ of the annual average sewerage service cost (calculated on the basis of the mean service cost of $€ 0.50$ per $\mathrm{m}^{3}$ ) on the "Potassique" sub-system. The remaining percentage of $6.8 \%$ concerns unexplained expenditures which are assigned to associated costs. Therefore, the estimation of the contribution of the territory analysed to the total sewerage service cost in the urban sewerage territory managed by the SIVOM, allows explaining and tracking about 57\% of the annual expenditure. $43 \%$ of the total direct cost remains unexplained due to the non-availability of operating data in the lease contract territory entrusted to LdE. Calculating the contribution of each activity in the average service cost allows prioritising the activities and identifying the most costly. Two activities impact on the cost of the SIVOM's urban sewerage territory, namely: 1) the wastewater/ stormwater treatment activities (31.75\%), followed by the waste management activity $(10.89 \%)$. These activities require auditing to plan improvement actions and optimise processes in order to reduce expenditure.

\section{Conclusion}

The work presented in this paper was performed to obtain better understanding of, and improve, the management of urban water systems. For practical reasons and in order to test the methodology, it was implemented on a subsystem of the UWMS, i.e. the wastewater system. The "Eco-EAR" methodology developed allows analysing the cost structure of the sewerage service, 
in order to diagnose its current operation, identify gaps and plan improvement actions for sustaining the system. The approach developed is innovative as it improves the technical and economic description of the subsystems composing the UWMS. The goals were to highlight the cost structure and possible dysfunctions in the operation of the system that may be possible sources of additional cost that must be reduced. Besides providing an economic assessment, our work focused on the sustainability of the sewerage system and its capacity to maintain the level of service required. To ensure the success of the methodology, several approaches for systems analysis were combined, including: i) functional analysis to define the boundaries of the wastewater system, to match the primary function, the secondary functions and the reference flow; ii) the Whole Life Cycle Cost Analysis (WLCA) used to assess the total annual cost by considering the annual operating expenditure, and the levelling out of capital expenditure, by taking into account the annual capital depreciation; and iii) Activity Based Costing (ABC) that breaks down each secondary function into activities and tasks in order to assess the corresponding resources consumed and the cost drivers incurred. The combination of all these approaches allowed crossing a process mapping approach with an economic approach for cost analysis. At the lowest level, the method has three advantages: i) it establishes an exhaustive list of relevant activities for providing a sewerage service; ii) it provides detailed knowledge of the cost activity drivers and clear understanding of the cost structure for identifying the activities with the highest impact; iii) it optimises the management of urban water systems; and iv) it establishes indicators for understanding and benchmarking equivalent wastewater systems. The first interesting result is the development of a structured and comprehensive "Eco-EAR" methodology characterised by interrelated levels of analysis. The second result concerns the implementation of the method which, despite missing or inaccurate data, makes it possible to perform a partial assessment based on the legal accounting documents available in the utility. This indicates that the method can be easily adapted for any subsystem of the UWMS. The results obtained are encouraging. Also, in spite of the difficulties of data and information gathering, it was possible to establish the interaction between the system's functions, activities and technical facilities, albeit partially. The understandable indicators were also evaluated. However, some improvements are needed to implement the method, although "Eco-EAR" provided a good description of the direct cost of the sewerage service provided. This raises the question of whether an assessed cost of sewerage is acceptable for the stakeholders. Is there a 
threshold of acceptability or rejection? How can we assess indirect costs and externalities, especially in the case of accidental or deliberate pollution? What about the potential opportunities or benefits that can or cannot be monetised? This requires considering the notion of acceptability and its impacts on the stakeholders involved. The second improvement concerns the assessment of indirect costs and potential benefits and how they can be measured, aggregated and mapped. The last relevant improvement concerns the extension of the methodology to the whole UWMS by considering all its component subsystems. All these aspects should be explored and developed in further research works.

\section{$7 \quad$ Acknowledgments}

The work presented is part of the French national project "OMEGA", reference number ANR-09VILL-004. It was funded by the National Research Agency (ANR). We are grateful to all the employees of the SIVOM of the Mulhouse region and "Lyonnaise des Eaux" who helped us in our research and provided us with data, information and advice. We would also to thank Mr Jean

De Combret from the company "Diadème" for providing us with his "Ecoval ${ }^{\circledR}$ " mapping software free of charge.

\section{$8 \quad$ References}

AFNOR, 2011. Management par la valeur - Analyse fonctionnelle, caractéristiques fondamentales Analyse fonctionnelle : analyse fonctionnelle du besoin (ou externe) et analyse fonctionnelle technique/produit (ou interne) - Exigences sur les livrables et démarches de mise en cuvre. Association Française de Normalisation, NF X50-100, November, 2011, France.

Alegre H., 2002. Performance indicators as a management support tool, Urban Water Supply Infrastructure Management Handbook,

Ashley, R., and Hopkinson, P., 2002. Sewer systems and performance indicators-into the 21 st century. Urban Water Journal, 4(2), 123-135.

Ashley, R., Jones, J., Ramella, S., Schofield, D., Munden, R., Zabatis, K., Rafelt, A., Stephenson, A., and Pallett, I., 2007. Delivering more effective stormwater management in the UK and Europe - lessons from the Clean Water Act in America. Proceeding of International conference NOVATECH2007, July 25-28, Lyon, France.

Australian Accounting Standard Board (AASB)., 2013. Property, plant and equipment. Melbourne: Australian Government.

Balkema A.J., Preisig H.A., Otterpohl R., Lambert F.J.D., 2002. Indicators for the sustainability assessment of wastewater treatment systems. Urban Water Journal, 4(2), 153-161. 
Bentarzi, Y., Terfous, A., Ghenaim, A., Wanko, A., Hlawka, F., and Poulet, J-B., 2013. Hydrodynamic characteristics of a new permeable pavement material produced from recycled concrete and organic matter. Urban Water Journal, 10(4), 260-267.

CERTU., 2003. La ville et son assainissement : principes, méthodes et outils pour une meilleure intégration dans le cycle de l'eau. Ministère de l'Ecologie et du Développement Durable, France, 2003. [CD ROM].

Chauvey J.N., Gérald N., 2004. Les apports de l'ABC à l'analyse stratégique : les enseignements d'une recherche-intervention. Finance Contrôle Strategie, 7(3), 63-89.

Chocat, B., Ashley, R., Marsalek, J., Matos, M.R., Rauch, W., Schilling, W., and Urbonas, B., 2007. Toward the Sustainable Management of Urban Stormwater. Indoor and Built Environment, 16 (3), 273-275.

Cherqui F., Baati S., Chocat B., Le Gauffre P., Granger D., Loubière B., Nafi A., Patouillard C., Tourne A., Toussaint J.-Y. ., Vareilles S. et Werey C., 2011. Approche systémique du système de gestion des eaux urbaines. Livrable L2a, programme OMEGA, ANR Villes Durables, 2009, France, pp.32. Available from: http://www.graie.org/OMEGA2/IMG/pdf/T2_livrable_L2a.pdf [Accessed November 2011]

Canadian Institute of Chartered Accountants (CICA)., 2007. Guide of accounting for and reporting tangible capital assets. City of Ottawa: Guidance of local Government and local Government Entities.

Direction Générale des Collectivités Locales., 2004. La comptabilité M49 des services d'eau et d'assainissement. Paris : Ministère de l'intérieur, de la sécurité intérieure et des libertés locales.

Dumax, N., 2009. La réparation économique du préjudice écologique. Revue Juridique de l'Environnement1, 51-57.

Palo, Alto., and Tetra, Tech., 2010. Sustainable water resources management, volume 3: case studies on new water paradigm. California: Electric Power Research Institute.

Eleutério, J., Hattemer, C., Rozan, A. 2011. A method to evaluate floods damage and consequences to network infrastructure and associated uncertainty. European Geosciences Union General Assembly 2011, April 03-08, Vienna, Austria.

Fane, S.A. 2005. Planning for sustainable urban water: systems-approaches and distributed strategies. Thesis (Phd), University of Technology, Sydney, Australia.

Fane, S., and Mitchell, C., 2006. Appropriate cost analysis for decentralised water systems.

Enviro 06 Conference and Exhibition, May 9-11, Melbourne, Australia.

Financial Reporting Standards (FRS15)., 1999. Tangible Fixed Assets. London: Accounting Standards Board.

Fletcher, T., 2009. Water sensitive cities; do we have what it takes to create them? Tenth International Conference on Computing and Control for the Water Industry. University of Sheffield, UK.
Mis en forme : Français (France)

Mis en forme : Français (France)

Mis en forme : Français (France)

Mis en forme : Français (France)

Mis en forme : Français (France) 
Granger, D., 2009. Méthodologie d'aide à la gestion durable des eaux urbaines. Thesis (Phd), Institut National des Sciences Appliquées de Lyon (INSA).

Grigg, N., 1999. A systemic approach to sustain and civilize urban water systems. EPA conference of futures of urban water systems, Austin, Texas, USA.

Hellström, D., Jeppsson, U., Karrman, E., 2000. A framework for systems analysis of sustainable urban water management. Environmental Impact Assessment Review, 20(03), 311-321.

Industrial Economics Incorporated, IEI.(1998). Cost Accounting and Budgeting for Improved Wastewater Treatment. Final report. Cambridge, MA,USA. 107 p.

International Financial Reporting Standards., 2012. Property, plant and Equipment. London: IFRS.

ISO., 2008. Bâtiments et biens immobiliers construits - prévision de la durée de vie - partie 5 : approche en coût global. Norme iso 15686-5:2008. Ávailable from: www.afnor.org. [A

Kraemer, R.A., Pielen, B, and Görlach, B. 2004. Economic dimension of integreated water resources management. Integrated Water Resources Management Course for the Central American Region, San José, Costa Rica. Available from: http://www.ecologic.eu/download/projekte/1850-1899/187205/1872-05presentation_kraemer.pdf. [Accessed May 2013]

Lim S-R., Lee H., and Park J.M., 2009. Life Cycle Cost Minimization of a Total Wastewater Treatment Network . Industrial and engineering Chemistry Research, 48(6), 2965-2971.

Matos, R., Cardoso, A., Ashley, R., Duartep., Molinari, A. and Schulz, A., 2003. Performance indicators for wastewater services - towards a manual of Best Practice. Water Science and Technology: Water Supply, 3(1-2), 365-371.

Matthews, W., De, Jager J., Van Harmelen, K., Wilson, I., and Duval, R., 2009. The development of an activity based costing model to quantify the real costs of delivering water services in rural areas. Pretoria: Water Research Comission

Novotny, V., and Brown, P., 2007. Cities of the future: Towards integrated sustainable water and landscape management. London (UK): The International Water Association.

Savic, D.A., Jordjevic, S., Cashman, A., Saul, A., 2008. A whole-life cost approach to sewerage and potable Water system management. In P. Hlavinek et al. (eds.), Dangerous Pollutants (Xenobiotics) in Urban Water Cycle, 3-12.Springer. ISBN 978-1-4020-6795-2 (e-book).

SIVOM., 2011. Rapport sur le prix et la qualité du service public de l'assainissement. Mulhouse: Syndicat Intercommunal à Vocation Multiple

Taylor, P., Gabbrielli, E., and Holmberg, J., 2008. Economics in sustainable water management: training manual and facilitators' guide. Union European: Cap-Net, GWP and EUWI-FWG.

Varis, O., 2005. Water and sustainable development: Paradigms, challenges and the reality. University partnerships for international development. Finland: Finland future research center.

Vouk, D., Malus, D., Halkijevic, I., 2011. Neural networks in economic analyses of wastewater systems. Expert Systems with Applications. 38(8), 10031-10035. 
Werey, C., Rozan, A., Wittner, C., Ghoulam, B., Soglo, Y., Larabi, Z., 2010. T8 - évaluation des impacts en fonction des vulnérabilités - recommandations pour l'évaluation économique des impacts - rapport projet ANR INDIGAU «Indicateurs de performance pour la gestion patrimoniale des réseaux d'assainissement urbains ». France : projet ANR-RGC\&U

Wong, T. \& Brown, R. (2008) Transitioning to water sensitive cities: ensuring resilience through a new hygro-social contract. In R, Ashley, and A.J, Saul (Eds.). 11th International Conference on Urban Drainage. September. Edinburgh. 10p.

MISTRA., 2013. The Swedish Foundation for Strategic Environmental Research. Available from: http://mistra.org/en/mistra/research/completed-research/sustainable-urban-water-management.html [Accessed May 2013].

NOVIWAM., 2013. The Novel Integrated Water Management Systems for Southern European Regions Duration. Available from: http://www.noviwam.eu [Accessed may 2013]

SWITCH., 2013. Sustainable Water Management Improves Tomorrows Cities Health, Framework 6 programme. Available from: http://www.switchurbanwater.eu [Accessed May 2013] 
Author-produced version of the article published in Urban Water Journal, 2014, 11 (6) 467-481 The original publication is available at http://www.tandfonline.com/ DOI: 10.1080/1573062X.2013.868497 